\title{
Entrepreneurial Orientation vs. Innovativeness of Small and Medium Size Enterprises
}

\author{
Joanna Ejdys \\ Associate Professor, Faculty of Management, Bialystok University of Technology, Poland, \\ 15-351 Bialystok, Wiejska 45A Street, e-mail: j.ejdys@pb.edu.pl \\ Project Management \\ Received December 7, 2014; received revisions December 19, 2014; June 10, 2015; June 19, 2015; accepted June 20, 2015 \\ Available online July 15, 2015
}

\begin{abstract}
This study aims to examine the role of entrepreneurial orientation (entrepreneurship orientation) in innovation level among Small and Medium Size Enterprises (SMEs). A questionnaire survey was conducted among 137 firms in the Podlaskie Region. Three hypotheses related to entrepreneurial orientation and innovativeness level were examined by Structural Equation Modeling (SEM). The relation between two constructs of entrepreneurial orientation and innovativeness, that is proactiveness and risk taking were analyzed. The research results show that proactiveness has a significant positive total effect on improving innovativeness. The findings suggest, in contrast to the strategic orientation literature, that risk taking deters enterprises from organizational innovation. The results confirmed the significantly higher impact of the risk taking as an intermediate variable on the innovation through the mediator of proactivity. This work examines the relations between entrepreneurial orientation and innovativeness, thus contributes to the strategic orientation literature.
\end{abstract}

Keywords: SMEs innovativeness, entrepreneurial orientation, proactiveness, risk taking.

\section{Introduction}

In comparison to other EU countries, the important role of Polish small and medium enterprises, in terms of the value of the generated GDP and jobs creation, is not consistent with the level of innovativeness in this sector. According to the Innovation Union Scoreboard (IUS), Poland belongs to the third group - the so-called moderate innovators, occupying the $25^{\text {th }}$ position out of $28 \mathrm{EU}$ countries. A characteristic feature of polish entrepreneurs is unbalanced potential for innovation, based mainly on human resources, with a very limited capacity for introducing innovation and R\&D cooperation. The Polish intellectual capital, as a relatively strong side, is therefore not fully exploited (Innovation Union Scoreboard 2014, 2014). Regarding the level of innovativeness of the SME sector, Poland occupies one of the last positions in the European Union. The results of research confirm that only $28 \%$ of Polish companies undertake any innovative activities at all, while the average for the EU is $52 \%$ (Entrepreneurship in the EU and beyond, Flash Eurobarometer, 2012). Among the 30 analyzed countries, the percentage of innovative small businesses in Poland represents $23 \%$ of all enterprises and it puts Poland in the penultimate place before Bulgaria (22\%) (Zadura-Lichota, 2013).

The literature review, the aim of which was to analyze determinants of innovation processes at the enterprise level, indicated that the lack of capacity for perspective thinking is a significant problem (Lumpkin and Dess, 1996; Radas and Bozic, 2009; Rahab, 2012; Huang and
Wang, 2011; Laukkanen, Nagy, Hirvonen, Reijonen and Pasanen, 2013; Rhee, Park and Lee, 2010). The reason for the low innovativeness of SMEs is often the lack of a systematic approach to strategic orientation. In the literature, the most often mentioned are three types of strategic orientation of small and medium-sized businesses, which determine their innovation: market orientation (marketing orientation), learning orientation and entrepreneurial orientation (Rhee et al., 2010). As the key factor of innovation is entrepreneurial orientation, it has become the subject of the author interest. According to meta-analysis conducted by Rauch et al. (2009) the studies concerning entrepreneurial orientation are still essential and they are very popular among researchers (Rauch, Wiklund, Lumpkin and Frese, 2009).

It is also important to be aware of the existing differences between the terms "entrepreneurship" and "entrepreneurial orientation" (Fig. 1). These differences are explained by Dess, Lumpkin, McGee. According to the authors "entrepreneurship" can be defined as a new entry, that is, the act of undertaking new venture, whereas entrepreneurial orientation is defined as a process, which includes methods, practices, decision making style the manager uses to act "entrepreneurially" (Dess et al., 1999). Between the analyzed constructs a cause and effect relationship exists.

In the literature, the object of scientific interest is usually the indicators describing a certain level of entrepreneurship, rather than the conditions for creating entrepreneurship at the level of the organization 
(entrepreneurial ori entation). Moreover, the analysis of the conditions favouring entrepreneurship is limited to external conditions. An example might be the creation of entrepreneurial attitudes at the level of primary or secondary school education, and a system of incentives from the state, favouring the creation of entrepreneurship.

The recent report of the Global Entrepreneurship Monitor published in 2014 reveals that, (Amoróz and Bosma, 2014) the level of entrepreneurship in Poland is still low and disturbing in relation to the average level for the whole of Europe. In $47.0 \%$ of cases, the lack of alternative work was the reason for setting up business. In the EU, the average rate of starting business under compulsion is $22.7 \%$ and in $47.0 \%$ of cases, the causes lie in the improvement activities. Poor indicators are the reason for the relatively high discontinuity of activity which manifests itself in closing up businesses. Specific indicators for Poland and EU, related to entrepreneurship, as a factor of innovation creation, are presented in Table 1.

The methodology for measuring entrepreneurship, used by the authors of the 2014 GEM report, only to a small extent reflects the overall range of entrepreneurial orientation. Outside the area of interest of the study are the qualities that reflect the level of risk taking in the conditions of uncertainty, or proactive attitudes related to "overtaking" or even aggressive entering the market, creating new value for the company. Being entrepreneurial does not always guarantee the creation of innovation. In-depth studies for examination of the characteristics of Polish entrepreneurship, which determines the level of innovation of small and mediumsized enterprises in Poland, remain relevant.

Bearing in mind the fact that innovativeness is the process of linking the resources of an organization, entrepreneurial orientation can facilitate the choice of the right resources for the organization and as a consequence improve the innovativeness (Wu et al., 2008).

The main scientific goal of the study is to identify the relationship between the one of the types of strategic orientation - entrepreneurial orientation and SMEs innovativeness. In particular, the author tries to answer the following question: How do the two constructs of entrepreneurial orientation, that is proactiveness and risk taking, influence innovativeness at organizational level?

\section{Theoretical Background and Hypotheses Development}

\subsection{Entrepreneurial Orientation}

Entrepreneurial orientation is the core of resource-based theory (Conner, 1991). This theory assumes that the resources necessary to compete on the market are ultimately dependent on entrepreneurial orientation. Entrepreneurial organizations are autonomic, often aggressive towards competition, active, innovative and ready to take risks.

Different meanings of "entrepreneurial orientation" construct, are presented in Table 2 . The vast majority of the definitions of entrepreneurial orientation refer to the organizational level and reflect the process approach manifested in: (i) commitment, (ii) risk acceptance and risk taking, (iii) creating an appropriate culture of entrepreneurship, (iv) use of practices, making entrepreneurial decisions and actions (v) ensuring dynamic development. Given the above, focusing on entrepreneurship is a kind of organizational culture, which provide to a higher level of entrepreneurship.

There is constantly a lively debate on the dimensionality of entrepreneurial orientation (Table 3). A comprehensive literature review of the dimension of entrepreneurial orientation can be found in the publication by Rautch et al. (Rauch et al., 2009). In relation to the three most frequently cited dimensions of entrepreneurship orientation (proactiveness, risk taking and innovativeness) Dees and Lumpkin (Dess and Lumpkin, 2005) have also proposed two additional dimensions that are critical to the entrepreneurial orientation concept: competitive aggressiveness and autonomy (Table 3). Authors claim that competitive aggressiveness is characterized by a warlike attitude or an aggressive reaction aiming at improving the position or overcoming any uncertainties in a competitive market. Autonomy, on the other hand, means the possibility to take independent actions within the organization, individual or collective, aiming at the realization of the business aims of the organization.

decision making style manager

undertaking new venture

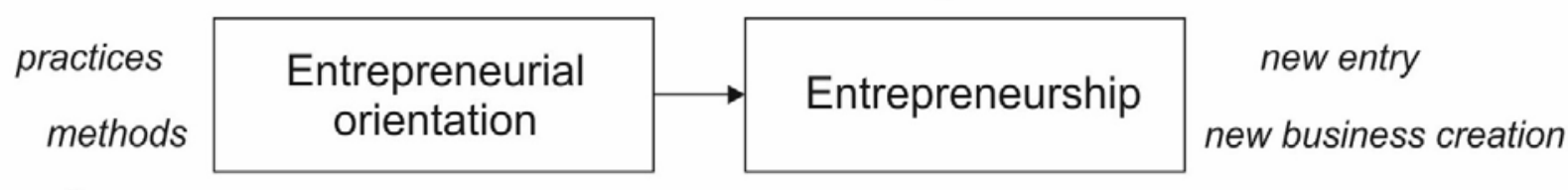

culture

entrepreneurial process

entering into the market for the first time

Internal environment External environment

Fig. 1. Differences between "entrepreneurship" and "entrepreneurial orientation" (elaboration based on Dess et al., 1999) 
Table 1. Entrepreneurial attitudes, perception and activities in Poland and UE-28 (2013) (Amoróz and Bosma, 2014)

\begin{tabular}{lcc}
\hline \multicolumn{1}{c}{ Entrepreneurial characteristics } & Poland & UE-28 \\
\hline Entrepreneurial attitudes and perception & & 28.7 \\
\hline Perceived opportunities & 26.1 & 42.3 \\
Perceived capabilities & 51.8 & 39.8 \\
Fear of failure & 46.7 & 13.5 \\
Entrepreneurial intentions & 17.3 & 56.9 \\
Entrepreneurship as a good career choice & 66.8 & 65.5 \\
High status to successful entrepreneurs & 59.9 & 49.0 \\
Media attention for entrepreneurship & 58.5 & \\
\hline Entrepreneurial activity & & 4.8 \\
\hline Nascent Entrepreneurship rate & 5.1 & 3.3 \\
New Business ownership rate & 4.3 & 8.0 \\
Early-stage Entrepreneurial activity (TEA) & 9.3 & 6.4 \\
Established business ownership rate & 6.5 & 2.9 \\
Discontinuation of Business & 4.0 & 22.7 \\
Necessity-driven & 47.0 & 47.0 \\
(\% of TEA) & 32.7 & \\
Improvement-driven opportunity (\% of TEA) & & \\
\hline
\end{tabular}

Bearing in mind that proactiveness is the readiness to take actions which would enforce a competitors' reaction, a proactive approach reflects the participation of the organization in the market of emerging industries, a constant search for and use of market weak signals to a quick reaction to the changing trends in the organizational environment (Miles and Snow, 1978). In other words, proactive behavior implies dynamic experimentation and realization of research and development policy aiming at maintaining a constant flow of new products or services introduced on the market (Perez-Luno et al., 2011). It should be expected that proactive organizations will scan the environment in order to find new trends and keep up with the competition. That is why proactiveness means also the forward-looking perspective, characteristic for a marketplace leader that has the ability to seize opportunities to predict the future demand (Dess and Lumpkin, 2005).

Risk taking largely reflects the organization's willingness to break away from the tried-and-true venture into the unknown (Chua, 2014; Perez-Luno et al., 2011). The management of risks is a growing area of concern (Ren et al., 2014) which can lead to a range of benefits for both projects and organisations. In case on innovative projects, it provides guidance for decision making about alternative options, increases confidence in the project success and reduces the risk of unexpected events that can cause delays and excess expenditure (Porananond and Thawesaengskulthai, 2014). There are three categories of risk: (i) risk connected with "setting off into the unknown" which means lack of knowledge of probability of achieving success; (ii) risk connected with investing big amounts of money in uncertain ventures and (iii) personal risk connected with potential negative consequences ending up with the failure of unpredictable and new professional challenges (Lumpkin and Dess, 1996). Indicated risk categories may occur simultaneously, thereby cause a risk accumulation. In case of the innovations implementation it can be expected that all three risk categories will occur in the same time.

The author of the paper took into account only two dimensions: proactiveness and risk taking. The competitive aggressiveness dimension was neglected because it is frequently identified in the literature and considered as a measure of proactivity. Excluding the dimension of autonomy from further analysis was due to the fact that the tested relations concern individual entities (enterprises), which are autonomous units on the market and all decisions are taken either individually or collectively within the unit. Therefore the organization's relationships with other market players forming the network's ties have not been taken into account. Autonomy also means ensuring, within the organizational framework of a unit, the possibility of building autonomous teams of people, characterized by creativity and making decisions. In this sense, the study would require a more detailed analysis concerning the existing organizational structures. 
Table 2. Definitions of entrepreneurial orientation

Authors

Miller, 1983

Lumpkin and Dess, 1996

Covin and Slevin, 1989

Dess and Lumpkin, 2005

Perez-Luno, Wiklund and Valle Cabrera, 2011

Liu, Ding, Guo and Luo, 2014
Definition of entrepreneurial orientation

Entrepreneurial orientation means engaging in product-market innovation, under-taking somewhat risky ventures and being first to come up with 'proactive' innovations, beating competitors to the punch"; suggesting the dimensions of innovativeness, risktaking, and proactiveness, respectively

Entrepreneurial orientation reflects the level of an organization's tendency to take risks, to be innovative and aggressive towards competitors

Entrepreneurial orientation means the process of transformation through the new combination of organization resources

Entrepreneurial strategic posture (orientation) is characterized by frequent and extensive technological and product innovation, aggressive competitive orientation, and strong risk taking propensity of the top management

Entrepreneurial orientation is found in companies where the strategic leaders and the culture together generate a strong impetus to innovate, take risks, and aggressively pursue new venture opportunities

Entrepreneurial orientation represents the policies and practices that provide a basis for entrepreneurial decisions and actions

Entrepreneurial orientation is a phenomenon that takes into account the process of planning, analyzing, decision making and at the same time reflecting organizational culture, the system of values and the mission of the company

Entrepreneurial orientation means firm's dynamic capabilities

Table 3. Dimension of entrepreneurial orientation

\begin{tabular}{|c|c|}
\hline Author & Dimension of entrepreneurial orientation \\
\hline $\begin{array}{l}\text { Boso, Story and Cadogan, 2013; G. G. Dess and Lumpkin, } \\
\qquad 2005\end{array}$ & $\begin{array}{ll}\text { - } & \text { Autonomy } \\
\text { - } & \text { Innovativeness } \\
\text { - } & \text { Proactiveness } \\
\text { - } & \text { Competitive aggressiveness } \\
\text { - } & \text { Risk taking } \\
\end{array}$ \\
\hline $\begin{array}{l}\text { Covin and Slevin, 1989; Miller, 1983; Miller and Friesen, } \\
1982\end{array}$ & $\begin{array}{ll}\text { - } & \text { Innovation } \\
\text { - } & \text { Proactiveness } \\
\text { - } & \text { Risk taking } \\
\end{array}$ \\
\hline Covin and Slevin, 1991 & $\begin{array}{ll} & \text { Risk taking } \\
\text { - } & \text { Product innovation and technological } \\
\text { - } & \text { Aggressiveness and proactiveness }\end{array}$ \\
\hline Slater and Narver, 2000 & $\begin{array}{ll}\text { - } & \text { Innovativeness } \\
\text { - } & \text { Risk-taking } \\
\text { - } & \text { Competitive aggressiveness }\end{array}$ \\
\hline Wang, 2008 & $\begin{array}{ll}- & \text { Innovativeness } \\
\text { - } & \text { Proactiveness } \\
\text { - } & \text { Aggressiveness } \\
\text { - } & \text { Risk taking } \\
\end{array}$ \\
\hline $\begin{array}{l}\text { Attuahene-Gima and Ko, 2001; Hult, Hurley and Knight, } \\
\text { 2004; Liu et al., 2014; Rhee et al., } 2010\end{array}$ & $\begin{array}{ll}\text { - } & \text { Proactiveness } \\
\text { - } & \text { Risk taking }\end{array}$ \\
\hline
\end{tabular}




\subsection{Entrepreneurial Orientation vs. Innovation}

Entrepreneurial orientation is the key factor of creation and implementation of innovation. Entrepreneurial orientation in relation to the innovation is the object of research in the context of the two main components of entrepreneurial orientation: proactivity and risk taking (Perez-Luno et al., 2011), types of innovation (Boso et al., 2013; Liu et al., 2014) innovation process (Perez-Luno et al., 2011) and innovation performance (Alegre and Chiva, 2013).

The conclusions of the study on the relationship between entrepreneurial orientation and innovation are presented in Table 4. Most authors exploring the relationship between entrepreneurship and innovation present a positive and strong impact on entrepreneurial orientation and the level of innovation of an enterprise.

This impact can be direct or indirect (including different factors as mediators). Wu et al. (2008) in their study pointed out the indirect relationship between the studied constructs and indicated that such characteristics as risk-taking, innovativeness, and proactiveness, which constitute entrepreneurial orientation, are crucial to complete implementation of intellectual capital in order to create higher levels of innovation.

Analyzing the direct impact of the two dimensions of entrepreneurial orientation, Perez-Luno et al., (2011) examined the relationship between pro-activity, ability to risk-taking, innovation and the dynamics of changes in the environment. The subject of their research concerned the two types of innovation: "new to the world" innovation generation and "new to the firm" innovation adoption. In terms of innovation implementation, authors found that proactivity and risk taking were positively associated with the number of internally generated innovations. Their study of the interaction effects between divisions of entrepreneurial orientation and environmental dynamics confirmed that in a dynamic environment the effects of the undertaken risk are much stronger than in the stable environment. The problem of taking into account the uncertainty of the environment and its dynamics, is a frequent topic of interest in the context of the desired, the most effective strategic orientation. The analyzed variables act as moderators during the tests.

Table 4. Entrepreneurial orientation and innovation as an object of research

\begin{tabular}{|c|c|c|c|c|c|}
\hline Author(s) & Country & Methods & Branch & Sample & Examined relationships \\
\hline $\begin{array}{l}\text { Wu et al., } \\
2008\end{array}$ & International & $\begin{array}{l}\text { Questionnaire } \\
\text { survey research } \\
\text { method }\end{array}$ & $\begin{array}{l}\text { Cross-sectional } \\
\text { samples }\end{array}$ & 159 & $\begin{array}{l}\text { Entrepreneurial orientation- } \\
\text { influence of the intellectual } \\
\text { capital on innovation }\end{array}$ \\
\hline $\begin{array}{l}\text { Perez-Luno et } \\
\text { al., } 2011\end{array}$ & Spain & $\begin{array}{l}\text { Survey research } \\
\text { method } \\
\text { Regression analysis } \\
\text { Hierarchical } \\
\text { fractional logit } \\
\text { analysis }\end{array}$ & Cross-sectional & 400 & $\begin{array}{l}\text { Proactivity-the number of } \\
\text { innovations adopted by a firm } \\
\text { Proactivity-the number of } \\
\text { innovations generated by a } \\
\text { firm } \\
\text { Risk taking-the number of } \\
\text { innovations generated by a } \\
\text { firm }\end{array}$ \\
\hline $\begin{array}{l}\text { Alegre and } \\
\text { Chiva, } 2013\end{array}$ & $\begin{array}{l}\text { Spain } \\
\text { Italy }\end{array}$ & $\begin{array}{c}\text { Survey approach } \\
\text { Confirmatory Factor } \\
\text { Analysis (CFA) } \\
\text { Structural equation } \\
\text { model (SEM) }\end{array}$ & Ceramic & 182 & $\begin{array}{l}\text { Entrepreneurial orientation- } \\
\text { innovation performance }\end{array}$ \\
\hline $\begin{array}{c}\text { Boso, } \\
\text { Cadogan et al., } \\
2013\end{array}$ & Ghana & $\begin{array}{l}\text { Confirmatory Factor } \\
\text { Analysis (CFA) } \\
\text { Structural equation } \\
\text { model (SEM) }\end{array}$ & $\begin{array}{l}\text { Internationally- } \\
\text { oriented small } \\
\text { businesses }\end{array}$ & 164 & $\begin{array}{l}\text { Entrepreneurial-oriented } \\
\text { behaviour- export product } \\
\text { innovation success }\end{array}$ \\
\hline $\begin{array}{l}\text { Liu et al., } \\
2014\end{array}$ & China & $\begin{array}{l}\text { Questionnaire } \\
\text { Survey research } \\
\text { method } \\
\text { Hierarchical multiple } \\
\text { regression analysis }\end{array}$ & High-tech & 308 & $\begin{array}{l}\text { Entrepreneurial orientation- } \\
\text { unabsorbed slack and product } \\
\text { innovation } \\
\text { Entrepreneurial orientation- } \\
\text { absorbed slack and product } \\
\text { innovation }\end{array}$ \\
\hline $\begin{array}{l}\text { Attuahene- } \\
\text { Gima and Ko, } \\
2001\end{array}$ & Australia & $\begin{array}{l}\text { Questionnaire } \\
\text { Survey research } \\
\text { method }\end{array}$ & Cross-sectional & 181 & $\begin{array}{l}\text { Entrepreneurial orientation- } \\
\text { product innovation }\end{array}$ \\
\hline
\end{tabular}


Attuahene-Gima and Ko analyzed the relationship between the two categories of orientation: marketing orientation and entrepreneurial orientation and product innovation. The authors proposed four profiles of companies with different degrees of orientation: market and enterprise. They distinguished the following categories of enterprises: market-oriented enterprises, companies focused on entrepreneurship, enterprises oriented more on entrepreneurship than the market and companies oriented more on the market than on entrepreneurship. The authors' findings suggested that marketing-entrepreneurial firms achieve higher new product performance, and are more effective in the product innovation process in several aspects than the enterprises which are oriented entrepreneurially only. Similar studies were conducted by Barefoot et al., where the object of their interest was small and medium-size exporters only. The authors analyzed the relationship between export entrepreneurial-oriented behaviour (EOB), export market-oriented behaviour (MOB) and product innovation. First of all, the results suggested that on fiercely competitive export markets it is extremely important to accept the two strategies EOB and MOB by the organization. The studies moreover confirmed that the strategy of export, which constitutes the combination of entrepreneurial orientated strategy and market based strategy, is more effective in strongly dynamic conditions than in a stable and predictable environment.

The main area of interest of the Miller and Friesen covers product innovations. Generally, firms may benefit from adopting an entrepreneurial orientation. Enterprises, which based their product-market strategies on risk-taking approach, seem to be more innovative (Miller and Friesen, 1982). The relationship between entrepreneurial orientation and other categories of innovation: process, marketing and organizational innovation has yet not been recognized.

Research conducted by Alegre and Chiva (2013) also concerned the relationship between entrepreneurial orientation and innovation performance, but in this case innovation performance acts as a mediating variable between entrepreneurial orientation and firm performance.

The conducted literature studies revealed that the entrepreneurial orientation recognized as a latent variable was mainly the subject of analysis with respect to the various dimensions that determine the choice of observable variables. The dimensions usually taken into account by the authors were analyzed as a whole, as those that make up the construct of entrepreneurial orientation. Furthermore, the obtained results did not allow assessing the impact of individual dimensions of entrepreneurial orientation on innovation. Therefore, the paper's author recognized the need for more in-depth analysis between the various dimensions of entrepreneurial orientation and the level of innovation. Assuming different levels of impact of individual dimensions of entrepreneurial orientation on innovation, it is advisable to examine them.

\subsection{Hypothesis Development}

According to other authors, entrepreneurial orientation construct has been conceptualized into two distinctive behavioural components: proactiveness and risk taking (Attuahene-Gima and Ko, 2001; Hult et al., 2004; Liu et al., 2014; Rhee et al., 2010).

The following hypotheses are proposed with respect to the relationships between types of entrepreneurial orientation and innovativeness (Fig. 2). It should be underscored that the model and hypotheses are specified for small and medium size enterprises.

H1: Proactiveness will significantly positively influence organizational innovativeness

H2: Risk taking will significantly positively influence organizational innovativeness

H3: Risk taking will significantly positively influence proactiveness

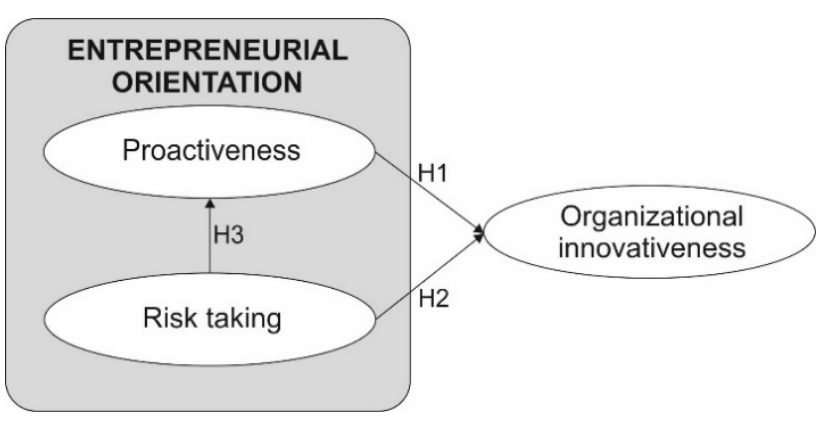

Fig. 2. Model and hypothesis

\section{Research Method}

\subsection{Data}

The data used to test the hypotheses were gathered from small and medium size enterprises from the Podlaskie region. The reported study is based on a cross-sectional survey on a sample of 137 SMEs, from Podlaskie region in Poland. Sample size used to estimate the SEM-based models is adviced to be smaller now than those used during the period of 1977-1994 (Ding, Velicer and Harlow, 1995; Martinez-Lopez et al., 2013). Ding et al. (1995) suggest the use of a minimum of 100-150 units to be examined.

The Podlaskie region was selected due to the low level of innovativeness of its enterprises, which recently has seemed to be the lowest in the country (Nazarko, 2011). Therefore, there is a need for the search for causes of such a low innovativeness as well as the identification of the best solutions to improve the state of innovativeness. The surveyed enterprises operate in various sectors, including production and services companies. Among them, 57.7 percent are micro companies (employment between 1-9 employees), 24.1 percent are small sized companies (employment between 10-49 employees) and 18.3 percent are medium firms (employment between 50-249 employees). Table 5 provides an overview of the SMEs that participated in this study.

More than $85 \%$ of surveyed units represent services, while almost $15 \%$ production sector. Surveyed enterprises were differentiated due to the market scope (extent) on which they conduct their business. Precisely $38 \%$ of surveyed units run their business on local market (local scale), nearly $25 \%$ - on regional market and $19 \%$ on 
national market. Sample of the surveyed enterprises was varied by company age. All age groups of enterprises were represented in the sample.

\subsection{Measures}

In this study, a survey method was used to collect data. The conducted literature studies confirmed that it is the most often used method (Table 4) for SEM purposes. Survey was based on the on-line questionnaire. A link to the website of the survey was sent to respondents between May 2014 and October 2014. Database with e-mail address of enterprises was taken from Central Registration and Information on Business, which is a professional database of Polish Ministry of Economy. Questionnaire was addressed to the managers of the organization. This fact was explained in the questionnaire introduction.

In relation to the developed model presented in Fig. 2, on the basis of the study of literature, measures have been identified. Due to the fact, that the examined constructs cannot be measured directly, the need to adopt direct measures appeared. The author adopted entrepreneurial orientation and innovativeness scale, which has been used in a variety of entrepreneurial orientation and innovativeness studies (Avlonitis and Salavou, 2007; Calantone et al., 2002; Rhee et al., 2010). Five items measured proactiveness, three items measured risk taking, five items measured the innovativeness level (Table 7). Based on Bollen (1989), it was recommended that each construct should be measured by at least three indicators.

Table 5. Profile of the respondent firms

\begin{tabular}{|c|c|c|}
\hline Characteristics of respondents & Frequency & Percentage \\
\hline \multicolumn{3}{|l|}{ Company categories } \\
\hline Production & 20 & 14.6 \\
\hline Services & 117 & 85.4 \\
\hline \multicolumn{3}{|c|}{ Employment size } \\
\hline $1-9$ & 79 & 57.7 \\
\hline $10-49$ & 33 & 24.1 \\
\hline $50-249$ & 25 & 18.2 \\
\hline \multicolumn{3}{|c|}{ Characteristics of the market } \\
\hline Local (one region) & 52 & 38.0 \\
\hline $\begin{array}{c}\text { Regional (several neighboring } \\
\text { provinces) }\end{array}$ & 34 & 24.8 \\
\hline National & 26 & 19.0 \\
\hline $\begin{array}{l}\text { International - neighboring } \\
\text { countries with Poland }\end{array}$ & 8 & 5.8 \\
\hline $\begin{array}{c}\text { International - European } \\
\text { Countries }\end{array}$ & 8 & 5.8 \\
\hline $\begin{array}{l}\text { Global (many countries on } \\
\text { different continents) }\end{array}$ & 9 & 6.6 \\
\hline \multicolumn{3}{|c|}{ Company age } \\
\hline Below 6 years & 28 & 20.4 \\
\hline Between 6-10 years & 20 & 14.6 \\
\hline Between $11-20$ years & 47 & 34.3 \\
\hline Between $21-50$ years & 32 & 23.4 \\
\hline Greater than 50 years & 10 & 7.3 \\
\hline \multicolumn{3}{|c|}{ Position of the respondent } \\
\hline Chairman of the board & 15 & 11.0 \\
\hline The manager/director & 54 & 39.4 \\
\hline Member of the board & 6 & 4.4 \\
\hline Owner & 55 & 40.1 \\
\hline Other position & 7 & 5.1 \\
\hline
\end{tabular}


All constructs were measured using a seven-point Likert scale to access the degree to which the respondent agreed or disagreed with each of the items (1=totally disagree to $7=$ totally agree). The constructs' Cronbach's alpha coefficients were used (ranging from 0.846 to 0.873 ) (Table 6).

Table 7 displays the final list of items, their sources, their respective standardized factor loadings. The positive and significant loadings confirm convergent validity of the measures. The factor loadings of observable variables for the latent variable of proactivity fit in the range of 0.483 to 0.772 , for the variable risk taking in the range of 0.623 to 0.819 , and for the variable innovation in the range of 0.314 to 0.879 . Only the OI4 variable factorial load is low, at the level of 0.313 , indicating a small observable impact of this variable on innovation.

\section{Analysis and Results}

\subsection{Measurement Model Results}

Having satisfied the requirement arising from measurement issues, the structural model in Fig. 1 was subsequently tested. The Generalizes Least Squares (GLS) model with AMOS was set to test the hypothesized relationships shown in Fig. 1. GLS is a technique for estimating unknown parameters in a linear regression model. In the structural equation modelling, a measurement model allows to set the relationships between observed variables (i.e. indicators) and their respective unobserved (latent) variables by defining a particular structural model (Bollen, 1989). In fact, Anderson and Gerbing (1988) recommended a two-stage approach in SEM, where the measurement model was developed before, and independently from, the structural model. According to Martinez-Lopez et al., (2013) authors have observed that this is now a usual practice in marketing, being adopted in 87 per cent of the SEM-based papers analyzed.

The appropriateness of the measurement model was evaluated by using the Chi-Square statistic. As Table 8 shows, the $\chi^{2}$ value was statistically significant $(\chi 2=87.26$, $\mathrm{p}<0.005)$ indicating good model fit to the data. As this measure is excessively conservative and is biased against large samples (Bollen, 1989; Joreskog and Sorbom, 1981), several disparate indices must be taken in to consideration jointly to evaluate an accurate reflection of the overall model fit. The indices included: The Root Mean Square Error of Approximation (RMSEA), the goodness-of-fit index (GFI), the adjusted goodness-of-fit index (AGFI) and comparative fit index (CFI). The results of the SEM test are provided in Table 8 . The approximate fits are also

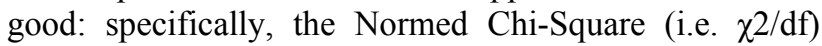
value $=1.407$ which is well within the acceptable range for this heuristic (Bentler and Chou, 1987; Bollen, 1989); RMSEA $=0.055$, is a good value (Bollen, 1989). This means that the model is likely to be interpreted as a real model of the relationship between the variables.

\subsection{Hypothesis Testing}

The hypotheses can be confirmed through the interpretation of the structural path coefficients. Moreover, the factor loadings for path proactiveness - organizational innovativeness and risk taking - proactiveness measurement items are significant.

The coefficient on the path from proactiveness to organizational innovativeness is $0.486(\mathrm{P}<0.001)$. Thus, this positive relationship suggests that hypothesis $\mathrm{H} 1$ is supported. The path coefficient from risk taking to proactiveness is $0.652(\mathrm{P}<0.001)$, which supports hypothesis 3 . The path coefficient from risk taking to organizational innovativeness is 0.20 , which led to rejection of the hypothesis $\mathrm{H} 2$ (Table 8).

The structural model explains $45.1 \%$, of the variance in the three unobserved, endogenous variables of theoretical constructs: proactiveness, risk taking and organizational innovativeness. Fig. 2 presents the individual structural path estimates. Table 8 reports the results for the structural model depicted in Fig. 2.

In the light of rejection the hypothesis $\mathrm{H} 2$ which assumed a direct relationship between the latent variable risk taking and innovation of enterprises, the indirect effects resulting from the impact of one variable on the other, in circumstances where the proactivity variable is a mediator, were analyzed. The basis for this type of analysis is contingency theory, which holds that the dependence between two variables is reliant on the third variable, often named moderator. Introducing moderators helps to reduce the potential for misleading inferences and permits a "more precise and specific understanding" (Rosenberg, 1968).

The results confirmed the significantly higher impact of the risk taking as an intermediate variable on the innovation through the mediator of proactivity. The standardized factorial load for the indirect impact of the risk taking variable on innovation is 0.304 , which gives the total direct effect at the level of 0,497 (Table 9).

\section{Conclusions}

Based on the findings, a number of guidelines can be offered to both scholars and practitioners regarding the role of entrepreneurial orientation in firm innovation.

The conducted literature studies confirmed the significant researchers' interest in the issues of relationship between the entrepreneurial orientation and the level of innovativeness (Laukkanen et al., 2013). In this study, a framework for studying entrepreneurial orientation and innovativeness was developed. The model was tested using data collected from small and medium size enterprises from the Podlaskie region. Examination of the relationship between entrepreneurial orientation and innovation may be particularly important in markets where strong competition appears and new products and technologies emerges. Poland represents such market.

The results support two of the hypotheses and reveal that proactiveness is critical for organizational innovation. Clearly, proactiveness influences firm innovativeness (coefficient $=0.49, \mathrm{p}<.001$ ). Proactive actions are the actions, for which the organization takes responsibility. The awareness of the choices results from knowledge and responsibility. Proactivity means to be a leader in introducing market changes, leads to innovation and results in the improvement of competitiveness of the individual. 
Table 6. Cronbach's alpha, means and standard deviations

\begin{tabular}{cccc}
\hline Examined constructs & Alpha & Mean & Standard deviation \\
\hline Proactiveness (PR) & 0.861 & 4.16 & 0.78 \\
Risk taking (RT) & 0.873 & 4.03 & 0.58 \\
Organizational innovativeness (OI) & 0.846 & 4.15 & 1.01 \\
\hline
\end{tabular}

Table 7. Constructs, measurement items and validity (Squared Multiple Correlations)

\begin{tabular}{|c|c|c|}
\hline & Items descriptions & Loadings \\
\hline \multicolumn{3}{|c|}{ Proactivity } \\
\hline PR1 & The organization offers more new products in relation to their competitors & 0.635 \\
\hline PR2 & Changes in the products often are radical & 0.483 \\
\hline PR3 & In an organization there is a strong emphasis on the creation of new innovative products & 0.647 \\
\hline PR4 & $\begin{array}{c}\text { In dealing with its competitors, our company typically initiates actions which competitors } \\
\text { then respond to }\end{array}$ & 0.718 \\
\hline PR5 & $\begin{array}{l}\text { In dealing with its competitors, our company is very often the first business to introduce } \\
\text { new products/services, administrative techniques, operating technologies }\end{array}$ & 0.772 \\
\hline \multicolumn{3}{|c|}{ Risk taking } \\
\hline RT1 & There is a tendency to take high-risk projects & 0.623 \\
\hline RT2 & In order to achieve the organization goals large-scale actions are often undertaken & 0.819 \\
\hline RT3 & $\begin{array}{c}\text { Typically, an organization adopts a bold, aggressive position to take advantage of } \\
\text { emerging opportunities }\end{array}$ & 0.685 \\
\hline \multicolumn{3}{|c|}{ Organizational Innovativeness } \\
\hline OI1 & Organization is characterized by the rapid process of innovation implementation & 0.559 \\
\hline OI2 & Organization is characterized by a higher level of innovation than competitors & 0.870 \\
\hline OI3 & $\begin{array}{c}\text { The value of sales of new or significantly improved products and services constitute a } \\
\text { significant share of the average annual sales }\end{array}$ & 0.665 \\
\hline OI4 & $\begin{array}{c}\text { The organization cooperate very closely with other stakeholders (business, science) in } \\
\text { research and development }\end{array}$ & 0.314 \\
\hline OI5 & $\begin{array}{c}\text { Members of the organization are encouraged to think and behave in an original and } \\
\text { innovative way }\end{array}$ & 0.455 \\
\hline
\end{tabular}

Table 8. Test hypotheses results

\begin{tabular}{cccccc}
\hline Relation between constructs & Estimate & S.E. & C.R. & P & $\begin{array}{c}\text { Hypothesis } \\
\text { testing }\end{array}$ \\
\hline Organizational innovativeness vs. proactiveness & 0.486 & 0.112 & 4.324 & $* * *$ & Support \\
Organizational innovativeness vs. risk taking & 0.200 & 0.115 & 1.749 & 0.08 & Reject \\
Proactiveness vs. risk taking & 0.652 & 0.103 & 6.349 & $* * *$ & Support \\
\hline $\begin{array}{c}\chi 2=87.26 ; \text { d.f. }=62 ; \chi 2 / \text { d.f. }=1.407 ; p<0.005 \\
\text { RMSEA }=0.055 ; \text { GFI }=0.901 ; \text { AGFI }=0.855 ; \text { CFI }=0.826, * * \\
\text { Adopted level of the statistical significance was } 0.05\end{array}$ & & \\
\hline
\end{tabular}




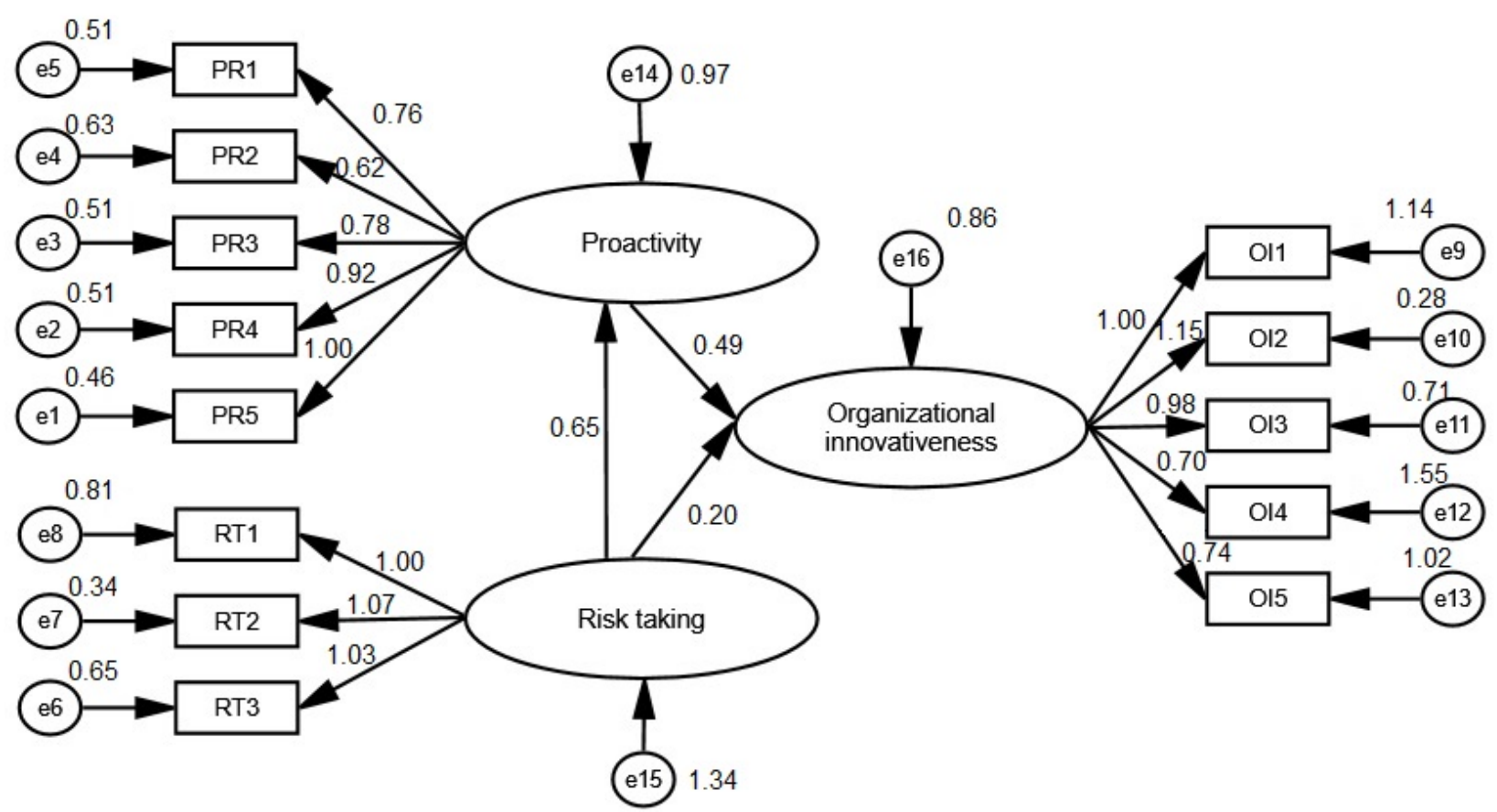

Fig. 2. Path coefficients (Standardized Regression Weights)

Table 9. Standardized direct effects

Effects

Risk taking vs. organizational innovativeness

$\begin{array}{cc}\text { Standardized direct effects } & 0.193 \\ \text { Standardized indirect effects } & 0.304 \\ \text { Standardized total effects } & 0.497\end{array}$

ConclusionsIn the light of the conducted studies and the rejection of hypothesis $\mathrm{H} 2$, there is no reason to indicate a direct positive relationship between risk taking and the innovativeness of companies in the group of surveyed enterprises. In this study, however, a significant relationship of intermediate nature of proactivity influence was observed. Risk taking would have a greater positive impact on the innovation of enterprises, only if there is a proactivity take into account. Risk taking associated with the investment of financial resources, entering new unfamiliar markets, and often taken up ad hoc, would decrease when managers adopt a proactive attitude manifested in experimenting, scanning the environment, and applying more perspective thinking. At the same time, it will result in a higher level of innovation.

Studies have also confirmed a significant, positive impact of the risk taking on proactive attitudes. This means that managers, and simultaneously the organizations led by them, accept risk-taking what influence the pro-activity. Such an effect may be a result of individual features of the manager, for instance by the means of his desire to risk-taking manifested in experimentation and willingness to make changes in the organization. Tendency to risk taking as individual attribute of manager, will have a greater positive impact on the level of innovation in organizations in case when new products and services are implemented into the market.
These activities should be ahead of the actions taken by competitors. Thus, the process of risk-taking in business should remain well-thought out and focused on large-scale actions. Large-scale actions mean that managers should not look for new products only, but also reflect to the process of implementation of organizational and marketing innovations.

As in most other studies, the results presented in the article can be interpreted with some limitations.

The first research limitation is its cross sectional character, without any orientation to a specific sector of the analyzed SME sector, what certainly limits the possibilities of in-depth analysis of existing casual relationships between entrepreneurial orientation and innovativeness. Consequently, the second limitation of this study was that its context (Podlaskie region) puts constraints on the generalizability of the results to other regions and national contexts. However, regional orientation of the studies has enabled to gain new knowledge about the role of entrepreneurial orientation in the context of innovativeness of the region and it has also enabled to demonstrate the universality and importance of the research in the context of global studies. The achieved results confirmed that, in case of region characterised by the low level of innovativeness, more valuable could be to demonstrate proactive attitude rather than to engage into 
high risk projects. Regional policy should focus on fostering entrepreneurial attitudes based on creativity. As opposed, engagement in high-risk projects can be an effective strategy in regions with already high level of innovativeness.

In the future research, it would be recommended to take into account the national context, to examine the existing relations between the entrepreneurial orientation and innovativeness on the national level. The third limitation is that this study focused on the effect of entrepreneurial orientation on firm innovativeness only, but the general outline can be applied to other types of orientations (such as marketing orientation and learning orientation) and their linkage with organizational innovativeness. The future research should focus on looking for links between other dimension of entrepreneurial orientation (autonomy, aggressiveness) and organizational innovativeness. The analysis of entrepreneurial orientation in the value chain seems to be also an interesting area of future research.

\section{References}

Alegre, J. and Chiva, R. (2013). Linking Entrepreneurial Orientation and Firm Performance: The Role of Organizational Learning Capability and Innovation Performance. Journal of Small Business Management, 51(4), 491-507.

Amoróz, J. E. and Bosma, N. (2014). Global Eentrepreneurship Monitor. 2014 Global Report.: Global Entrepreneurship Research Association (GERA).

Attuahene-Gima, K. and Ko, A. (2001). An empirical investigation of the effect of market orientation and entrepreneurship orientation alignment on product innovation. Organization Science, 12(1), 54-74.

Avlonitis, G. J. and Salavou, H. E. (2007). Entrepreneurial orientation of SMEs, product innovativeness, and performance. Journal of Business Research, 60(5), 566-575.

Bentler, P. M. and Chou, C. P. (1987). Practical issues in structural modeling. Sociological Methods and Research, 16(1), 78-117.

Bollen, K. A. (1989). Structural Equations with Latent Variables. New York: John Wiley and Sons.

Boso, N., Cadogan, J. W., and Story, V. M. (2013). Entrepreneurial orientation and market orientation as drivers of product innovation success: A study of exporters from a developing economy. International Small Business Journal, 31(1), 57-81.

Boso, N., Story, V. M., and Cadogan, J. W. (2013). Entrepreneurial orientation, market orientation, network ties, and performance: Study of entrepreneurial firms in a developing economy. Journal of Business Venturing, 28(6), 708-727.

Calantone, R. J., Cavusgil, S. T., and Zhao, Y. S. (2002). Learning orientation, firm innovation capability, and firm performance. Industrial Marketing Management, 31(6), 515-524.
Conner, K. R. (1991). A historical comparison of resource-based theory and five schools of thought within industrial organization economics: do we have a new theory of firms? Journal of Management, 17(1), 121-154.

Covin, J. G. and Slevin, D. P. (1989). Strategic management of small firms in hostile and benign environment. Strategic Management Journal, 10, 7587.

Covin, J. G. and Slevin, D. P. (1991). A conceptual model of entrepreneurship as firm behavior. Entrepreneurship: Theory and Practice, 1(September), 7-25.

Dess, G. G., Lumpkin G.T., and McGee, J. E. (1999). Linking corporate entrepreneurship to strategy, structure, and process: suggested research directions. Entrepreneurship Theory and Practice, 1(March), 85102.

Dess, G. G. and Lumpkin, G. T. (2005). The role of entrepreneurial orientation in stimulating effective corporate entrepreneurship. Academy of Management Executive, 19(1), 147-156.

Ding, L., Velicer, W. F., and Harlow, L. L. (1995). Effects of estimation methods, number of indicators per factor, and improper solutions on SEM fit indices. Structural Equation Modeling, 2, 119-143.

Entrepreneurship in the EU and beyond, Flash Eurobarometer. (2012). Brussels: European Commission.

Hult, G. T. M., Hurley, R. F., and Knight, G. A. (2004). Innovativeness: Its antecedents and impact on business performance. Industrial Marketing Management, 33(5), 429-438.

Innovation Union Scoreboard 2014. (2014). Brussels: European Commision.

Joreskog, K.G. and Sorbom, D. (1981). LISREL User's guide, Chicago, National Educational Services.

Laukkanen, T., Nagy, G., Hirvonen, S., Reijonen, H., and Pasanen, M. (2013). The effect of strategic orientations on business performance in SMEs A multigroup analysis comparing Hungary and Finland. International Marketing Review, 30(6), 510-535.

Liu, H., Ding, X.-h., Guo, H., and Luo, J.-h. (2014). How does slack affect product innovation in high-tech Chinese firms: The contingent value of entrepreneurial orientation. Asia Pacific Journal of Management, 31(1), 47-68.

Lumpkin, G. T. and Dess, G. G. (1996). Clarifying the entrepreneurial orientation construct and linking it to performance. Academy of Management Review, 21(1), $135-172$.

Martinez-Lopez, F. J., Gazquez-Abad, J. C., and Sousa, C. M. P. (2013). Structural equation modelling in marketing and business research Critical issues and practical recommendations. European Journal of Marketing, 47(1-2), 115-152. 
Miles, R. E. and Snow, C. C. (1978). Organizational Strategy, Structure, and Process. New York: McGraw-Hill.

Miller, D. (1983). The correlates of enterpreneurship in three types of firm. Management Science, 29, 770-791.

Miller, D. and Friesen, P. H. (1982). Innovation in Conservative and Entrepreneurial Firms: Two Models of Strategic Momentum. Strategic Management Journal, 3, 1-25.

Perez-Luno, A., Wiklund, J., and Valle Cabrera, R. (2011). The dual nature of innovative activity: How entrepreneurial orientation influences innovation generation and adoption. Journal of Business Venturing, 26(5), 555-571.

Porananond, D. and Thawesaengskulthai, N. (2014). Risk Management for New Product Development and Projects in Food Industry. Journal of Engineering, Project, and Production Management, 4(2), 99-113.

Radas, S. and Bozic, L. (2009). The antecedents of SME innovativeness in an emerging transition economy. Technovation, 29(6-7), 438-450.

Rauch, A., Wiklund, J., Lumpkin, G. T., and Frese, M. (2009). Orientation and business performance: an assessment of past research and suggestions for the Future. Entrepreneurship Theory and Practice, 33(3), 761-787.

Ren, Y., Yeo, K. T., and Ren, Y. (2014). Risk Management Capability Maturity and Performance of Complex Product and System (CoPS) Projects with an Asian Perspective. Journal of Engineering, Project, and Production Management, 4(2), 81-98.

Rhee, J., Park, T., and Lee, D. H. (2010). Drivers of innovativeness and performance for innovative SMEs in South Korea: Mediation of learning orientation. Technovation, 30(1), 65-75.

Rosenberg, M. (1968). The logic of survey analysis. New York: Basic Books.

Slater, S. F. and Narver, J. C. (2000). The positive effect of a market orientation on business profitability: A balanced replication. Journal of Business Research, 48(1), 69-73.

Wang, C. L. (2008). Entrepreneurial orientation, learning orientation, and firm performance. Entrepreneurship Theory and Practice, 32(4), 635-657.

Wu, W.-Y., Chang, M.-L., and Chen, C.-W. (2008). Promoting innovation through the accumulation of intellectual capital, social capital, and entrepreneurial orientation. $R$ and D Management, 38(3), 265-277.

Zadura-Lichota, P. (2013). Świat innowacyjnego społeczeństwa [World of innovative society]. Trendy na najbliższe lata. Warszawa: PARP.

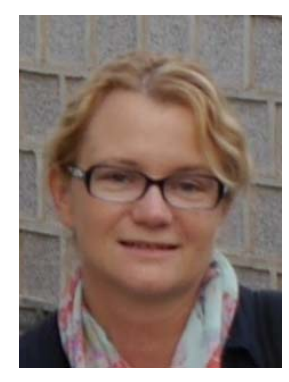

Dr. Joanna Ejdys, is currently an Associate Professor at Faculty of Management, Bialystok University of Technology, Poland. She is a Vice Dean for Research and Development and Editor of Economics and Management Journal. Research interest: quality management, foresight studies, strategic management and technology management. Her research area of interest include: corporate foresight for SMEs, strategic orientation and entrepreneurial orientation. She has published more than 30 papers on foresight studies concerning regional and national science and technology innovation policy. 